\title{
KEPUTUSAN INVESTASI, PENDANAAN, KEBIJAKAN DIVIDEN TERHADAP KINERJA KEUANGAN DAN NILAI PERUSAHAAN
}

\author{
Gita Anggia \\ 154010005@gmail.unpas.ac.id \\ Jaja Suteja \\ Universitas Pasundan
}

diterima: 3/4/2019; direvisi: 12/5/2019; diterbitkan: 31/8/2019

\begin{abstract}
This research aims to determine how the investment and financial decision and dividend policies give influences and impact on financial performance and value of property company, real estate, and building construction companies listed on the Indonesia Stock Exchange in the period of 2012-2017. The research method used is descriptive and verificative method with sample of 17 companies. Data collection techniques used are literature and online-research study. The data analysis method used is regression analysis. The results showed that investment and financial decision and dividend policy have simultaneous effect to financial performance, namely about $22.50 \%$, while partially about $10.00 \%, 7.78 \%$, and $4.72 \%$ each. This research also provides an effect of financial performance to company value about $33.7 \%$.
\end{abstract}

Keywords: investment decision; financial decision; dividend policy; financial performance; Company Value

\begin{abstract}
Abstrak
Penelitian ini bertujuan untuk mengetahui pengaruh keputusan investasi, keputusan pendanaan, dan kebijakan dividen terhadap kinerja keuangan dan dampaknya terhadap nilai perusahaan properti, real estate, dan konstruksi bangunan yang terdaftar di Bursa Efek Indonesia periode 2012-2017. Metode yang digunakan adalah deskriptif dan verifikatif dengan jumlah sampel 17 perusahaan. Teknik pengumpulan data yang digunakan adalah penelitian pustaka dan online. Metode analisis data yang digunakan adalah analisis regresi. Hasil penelitian menunjukkan bahwa keputusan investasi, keputusan pendanaan, dan kebijakan dividen secara bersama-sama mempengaruhi kinerja keuangan sebesar $22,50 \%$, sedangkan secara parsial mempengaruhi kinerja keuangan masing-masing sebesar 10,0\%, 7,78\% dan 4,72\%. Selanjutnya kinerja keuangan berpengaruh terhadap nilai perusahaan sebesar $33,7 \%$.
\end{abstract}

Kata Kunci: keputusan investasi; keputusan pendanaan; kebijakan dividen; kinerja keuangan; nilai perusahaan 


\section{PENDAHULUAN}

Bertambahnya jumlah perusahaan baru membuat persaingan dunia bisnis di Indonesia semakin ketat. Perusahaan yang bergerak di bidang jasa, manufaktur, maupun dagang saling bersaing untuk dapat bertahan dan menjadi yang terbaik. Hal ini mendorong masingmasing perusahaan untuk melakukan berbagai inovasi dan strategi bisnis agar terhindar dari kebangkrutan.

Penelitian ini akan menggunakan sector properti, real estate, dan konstruksi bangunan periode 2012-2017 karena memiliki rata-rata harga saham paling rendah dibanding sektor yang lain (Gambar 1), sedangkan harga properti secara individual semakin mahal. Faktor lainnya adalah perkembangan sektor ini juga merupakan salah satu indikator pertumbuhan ekonomi negara.

Tujuan utama perusahaan yaitu maksimalisasi nilai melalui kemakmuran pemilik yang ditunjukkan dengan meningkatnya harga saham (Sari, 2013). Nilai perusahaan merupakan nilai pasar yang mampu memberikan kemakmuran bagi pemegang saham secara maksimum jika harga saham meningkat. Semakin tinggi harga pasar saham maka semakin tinggi nilai perusahaan, semakin terjamin kesejahteraan dan kemakmuran para pemegang saham, sehingga semakin banyak investor yang akan bersedia menginvestasikan uangnya di perusahaan. Manajemen suatu perusahaan harus menetapkan pilihan yang tepat mengenai struktur modal dan kebijakan dividen yang akan mempengaruhi nilai perusahaan (Manjunath, 2013). Nilai perusahaan merupakan persepsi investor terhadap perusahaan yang sering dikaitkan dengan harga saham. Nilai perusahaan yang tinggi menjadi keinginan para pemilik perusahaan, karena menunjukkan kemakmuran pemegang saham juga tinggi (Hemastuti, 2014).

Rasio untuk mengukur nilai pasar perusahaan selain melihat dari harga saham adalah Price Book Value (PBV). Rasio ini memberikan gambaran potensi pergerakan harga saham. PBV menunjukkan apakah harga pasar saham diperdagangkan di atas atau di bawah nilai bukunya (Syahyunan, 2013). Kondisi rata-rata nilai perusahaan yang diukur dengan PBV berfluktuasi cenderung menurun (Gambar 2), yang diakibatkan adanya perubahan harga dan nilai buku saham perusahaan.

Peningkatan nilai perusahaan dipengaruhi oleh kinerja keuangan, merupakan aspek penilaian yang dimiliki perusahaan (Wiagustini, 2010 dalam Dewi dan Suardana, 2015). Penelitian ini menggunakan Return on Equity (ROE) sebagai pengukurannya, karena menggambarkan keuntungan yang dihasilkan modal sendiri atau kemampuan menghasilkan laba atas suatu investasi (Hagel, et. al., 2013). Hasil penelitian Rahman, et. al. (2015); Dewi dan Wirajaya (2013) menujukkan profitabilitas berpengaruh secara signifikan terhadap nilai perusahaam. Kondisi rata-rata kinerja keuangan ROE periode 2012-2017 berfluktuasi dan cenderung menurun (Gambar 3), karena modal sendiri yang meningkat namun tidak diikuti dengan meningkatnya laba bersih.

Kombinasi optimal dari kinerja keuangan akan memaksimumkan nilai perusahaan. Manajemen keuangan menyangkut penyelesaian atas keputusan penting yang diambil perusahaan, antara lain keputusan investasi. Keputusan investasi merupakan salah satu bagian dari fungsi manajemen keuangan perusahaan. Manajemen keuangan harus mengalokasikan dana ke dalam bentuk investasi yang menguntungkan di masa mendatang.

Keputusan investasi merupakan keputusan penting dalam hubungannya dengan peningkatan nilai perusahaan. Keputusan investasi pada dasarnya adalah keputusan untuk mengalokasikan sumber dana atau penggunaan dana. Efisiensi penggunaan dana secara langsung akan menentukan besar kecilnya tingkat keuntungan yang dihasilkan atas investasi (Syahyunan, 2015:1). Keputusan investasi menurut Sutrisno (2012) adalah masalah bagaimana manajer keuangan harus mengalokasikan dana ke dalam bentuk-bentuk investasi yang akan dapat mendatangkan keuntungan di masa datang. Keputusan investasi sangat penting karena berpengaruh terhadap pencapaian visi dan misi perusahaan. Keputusan investasi diukur dengan Price Earning Ratio (PER) yang menggambarkan harapan pasar tentang pertumbuhan di masa datang dihubungkan dengan risiko (Wu, 2013) dan mempunyai peran penting bagi investor (Wu, 2014; Gottwald, 2012). PER merupakan indikator yang menunjukkan minat investor untuk membayar atas laba yang diperoleh (Sezgin, 2010), indikator pendapatan sementara dan masa datang juga risiko (Apergis, et. al., 2015). PER yang tinggi menunjukkan peningkatan kinerja saham di masa datang (Ong, et. al. 2010), berarti pasar mengharapkan pertumbuhan laba di masa datang (Gottwald, 2012). Penelitian Ardimas dan Wardoyo (2014) menyatakan bahwa keputusan investasi berpengaruh pada kinerja keuangan. Kondisi rata-rata PER berfluktuasi (Gambar 4). Penurunan PER menunjukkan perusahaan mengalami penurunan pertumbuhan laba sehingga tingkat pengembalian yang akan diterima investorpun menurun.

Keputusan pendanaan adalah keputusan tentang upaya memperoleh dana untuk membiayai investasi. Manajer keuangan harus selalu mencari alternatif sumber dana untuk kemudian dianalisis dan harus diambil keputusan alternatif sumber dana atau kombinasi sumber dana yang akan dipilih (Syahyunan, 2015:2). Menurut Hilmi (2010) dalam Nurcahayani dan Daljono (2014) menyatakan bahwa sumber pendanaan perusahaan umumnya didapatkan dari pendanaan internal berupa modal sendiri atau modal pemilik dan pendanaan eksternal berupa hutang. Perusahaan yang tidak menggunakan hutang berarti struktur modalnya terdiri dari modal pemilik, akan tetapi kebanyakan struktur 
modal perusahaan berhubungan dangan hutang dan modal sendiri yang mengakibatkan manajer keuangan sangat sensitif dan secara akurat menerima hutang dan pengaruhnya terhadap kesejahteraan pemegang saham (Fengju, et. al., 2013). Penurunan proporsi penggunaan hutang menggambarkan ketidaksediaan untuk mengambil risiko keuangan dan mengalihkannya kepada pemegang saham (Kazmierska-Jozwiak, et. al., 2015). Hasil penelitian Lenka (2017) menunjukkan bahwa debt ratio mempunyai pengaruh terhadap kinerja perusahaan. Hasil penelitian Nurcahayani dan Daljono (2014); Dewi dan Wirajaya (2013); Hantono (2015) menunjukkan bahwa DER memiliki pengaruh yang signifikan terhadap ROE dengan arah yang negatif. Sedangkan penelitian Marinda, et. al. (2014); Murniati, et. al.(2019); Nopitasari, et. al. (2014); Utamayasa dan Suputra (2016) menunjukkan struktur modal (keputusan pendanaan) berpengaruh positif dan signifikan terhadap kinerja keuangan.

Keputusan pendanaan merupakan keputusan penting yang dibuat oleh perusahaan. Manajer keuangan memerlukan metode yang baik untuk mengoptimalkan pembiayaan menggunakan hutang atau ekuitas untuk memaksimalkan kinerja perusahaan (Daud et. al. 2016). Kondisi rata-rata keputusan pendanaan yang diukur dengan Debt Equity Ratio (DER) berfluktuasi cenderung menurun (Gambar 5). Semakin kecil nilai DER, maka semakin baik posisi utang perusahaan, hal ini menunjukkan bahwa jumlah utang yang dibiayai oleh modal sendiri semakin kecil.

Kebijakan dividen adalah keputusan apakah laba yang diperoleh perusahaan pada akhir tahun akan dibagi kepada pemegang saham dalam bentuk dividen atau akan ditahan untuk menambah modal guna pembiayaan investasi di masa yang akan datang (Syahyunan, 2015). Dividen adalah isu yang penting bagi investor sebagai sumber pendapatan dan memberikan informasi tentang kinerja perusahaan (Ardestani, et.al. 2013). Dividend Payout Ratio (DPR) menggambarkan bagian laba yang dibayarkan ke pemegang saham. DPR sama dengan $100 \%$ berarti kebijakan yang secara total didekasikan bagi pemegang saham, sebaliknya $0 \%$ menggambarkan tidak adanya laba yang dibagikan sebagai dividen, dengan berbagai alasan guna keperluan investasi. Apabila perusahaan memutuskan untuk membagi laba yang diperoleh sebagai dividen berarti akan mengurangi jumlah laba yang ditahan yang akhirnya juga mengurangisumber dana intern. Sedangkan apabila perusahaan tidak membagi labanya sebagai dividen akan dapat memperbesar sumber dana intern dan akan meningkatkan kemampuan untuk mengembangkan perusahaan (Hermastuti dan Hermanto, 2014). Hasil penelitian Anandasayanan dan Velmampy (2016) menunjukkan bahwa kebijakan dividen berpengaruh signifikan terhadap profitabilitas. Peningkatan DPR akan berpengaruh positf terhadap pertumbuhan pendapatan di masa datang (Flint, et. al., 2010). Perusahaan dengan
DPR yang tinggi dan stabil adalah perusahaan bluechips (Kibet, et. al. 2010). Kondisi rata-rata DPR berfluktuasi (Gambar 6), yang disebabkan perubahan kebijakan pembagian dividen kepada para pemegang saham di setiap tahunnya.

Rumusan masalah adalah: (1) Bagaimana kondisi keputusan investasi, keputusan pendanaan, kebijakan dividen, kinerja keuangan dan nilai perusahaan, (2) Seberapa besar pengaruh keputusan investasi, keputusan pendanaan dan kebijakan dividen terhadap kinerja keuangan secara simultan maupun parsial, (3) Seberapa besar pengaruh kinerja keuangan terhadap nilai perusahaan sektor properti, real estate, dan konstruksi bangunan yang terdaftar di BEI Tahun 2012 - 2017.

\section{METODE}

Metode penelitian yang digunakan adalah metode deskriptif dan verifikatif. Metode deskriptif digunakan untuk mengetahui keputusan investasi, pendanaan, kebijakan dividen, kinerja keuangan, dan nilai perusahaan sector properti, real estate, dan konstruksi bangunan yang terdaftar di Bursa Efek Indonesia periode 2012-2017. Populasi berjumlah 20, penentuan sampel dengan purposive sampling dengan kriteria: (1) terdaftar di BEI tahun 2012 - 2017, (2) membagikan dividen, dan (3) memiliki laporan keuangan lengkap. Total sampel sebanyak 17 perusahaan. Analisis data dilakukan dengan menggunakan analisis regresi.

\section{HASIL}

Kondisi rata-rata keputusan investasi (PER) perusahaan properti, real estate, dan konstruksi bangunan yang terdaftar di BEI Periode 2012-2017 berfluktuasi, menurun pada tahun 2012 kemudian meningkat sampai dengan tahun 2016 dan menurun pada tahun 2017 (Tabel 1). Kondisi rata-rata keputusan pendanaan (DER) berfluktuasi cenderung menurun (Tabel 2). Kondisi rata-rata kebijakan dividen (DPR) berfluktuasi, meningkat pada tahun 2013, kemudian menurun pada tahun 2014 dan 2015, meningkat pada tahun 2016, dan menurun kembali tahun 2017 (Tabel 3). Kondisi rata-rata kinerja keuangan (ROE) berfluktuasi cenderung menurun (Tabel 4). Kondisi rata-rata nilai perusahaan (PBV) turut berfluktuasi cenderung menurun (Tabel 5).

Data memiliki distribusi normal dan mempunyai hubungan linier. Hasil analisis regresi persamaan I ditunjukkan pada Tabel 6 dan persamaan II pada Tabel 7.

$$
\begin{aligned}
& \text { Kinerja Keuangan }=4,037-0,428 \text { Keputusan Investasi }+ \\
& 0,637 \text { Keputusan Pendanaan }+0,128 \\
& \text { Kebijakan Dividen }+\varepsilon
\end{aligned}
$$

Nilai Perusahaan $=0,416+0,254$ Kinerja Keuangan +

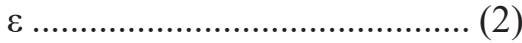


Besarnya pengaruh keputusan investasi, keputusan pendanaan, dan kebijakan dividen terhadap kinerja keuangan pada perusahaan properti, real estate, dan konstruksi bangunan periode 2012-2017 sebesar 22,50\% (Tabel 8). Kontribusi pengaruh keputusan investasi terhadap kinerja keuangan adalah 10,00\%, keputusan pendanaan adalah 7,78\%, dan kebijakan dividen sebesar $4,72 \%$. Kinerja keuangan berpengaruh positif dan signifikan terhadap nilai perusahaan sebesar $33,7 \%$ (Tabel 9)

\section{PEMBAHASAN}

PER tertinggi terjadi pada tahun 2016 sebesar 18,55. Rasio PER yang lebih tinggi menunjukkan bahwa pasar bersedia membayar lebih terhadap laba perusahaan, serta memiliki harapan yang tinggi terhadap masa depan perusahaan tersebut sehingga bersedia untuk menghargainya dengan harga yang lebih tinggi. PER yang tinggi menunjukkan peningkatan kinerja saham di masa datang (Ong, et. al. 2010), berarti pasar mengharapkan pertumbuhan laba di masa datang (Gottwald, 2012).

Tingkat tertinggi DER terjadi pada tahun 2013 sebesar 1,87. Semakin tinggi tingkat DER, berarti komposisi hutang juga semakin tinggi. Investor harus jeli dalam melihat DER, sebab jika total hutangnya lebih besar dari pada ekuitas, maka harus dilihat lebih lanjut apakah hutang lancer atau hutang jangka panjang yang lebih besar. Jika hutang lancer lebih besar dari pada hutang jangka panjang, hal ini masih dapat diterima, karena besarnya hutang lancer sering disebabkan oleh hutang operasi yang bersifat jangka pendek. Jika hutang jangka panjang yang lebih besar, maka dikhawatirkan perusahaan akan mengalami gangguan likuiditas di masa datang. Penurunan proporsi penggunaan hutang menggambarkan ketidaksediaan untuk mengambil risiko keuangan dan mengalihkannya kepada pemegang saham (Kazmierska-Jozwiak, et. al., 2015).

DPR rata-rata berfluktuasi dan tertinggi terjadi pada tahun 2015 sebesar 23,80\%. Umumnya perusahaan dengan DPR tinggi memiliki jumlah kas yang besar, tidak lagi membutuhkan laba untuk ditahan. Perusahaan dengan DPR yang tinggi dan stabil adalah perusahaan bluechips (Kibet, et. al. 2010). PT. Total Bangun Persada TBK. (TOTL) memiliki DPR paling tinggi mencapai lebih dari 50\% dan bertahan selama tahun 2012-2017.

ROE berfluktuasi dan memiliki kecenderungan menurun. Hal tersebut terjadi diakibatkan oleh adanya penurunan laba setelah pajak, sementara total ekuitas perusahaan meningkat atau stagnan di beberapa perusahaan. Tingkat tertinggi terjadi pada tahun 2013 sebesar $19,52 \%$. Tingkat terendah terjadi pada tahun 2016 sebesar 10,60\%. PBV berfluktuasi dan memiliki kecenderungan menurun. Penurunan terjadi diakibatkan oleh adanya perubahan harga saham dan perubahan nilai rata-rata buku perusahaan. Tingkat tertinggi terjadi pada tahun 2014 sebesar 2,99. Semakin tinggi PBV semakin baik prospek perusahaan. Tingkat terendah terjadi pada tahun 2017 sebesar 1,31.

Hasil penelitian menunjukkan keputusan investasi, keputusan pendanaan, dan kebijakan dividen mempunyai pengaruh secara simultan terhadap kinerja keuangan sebesar $22,50 \%$. Keputusan investasi berpengaruh negatif dan signifikan terhadap kinerja keuangan sebesar $10 \%$. Hal ini berarti keputusan investasi yang tinggi maka tingkat profitabilitas rendah, sesuai dengan teori yang dikemukakan Ohlson and Zan (2006) dalam Wu (2014) bahwa PER mempunyai hubungan berbentuk U (U-shaped) dengan ROE. Perusahaan dengan PER tinggi akan memperoleh ROE yang rendah.

Keputusan pendanaan berpengaruh positif signifikan terhadap kinerja keuangan sebesar 7,78\%. Berarti penambahan utang meningkatkan pendapatan bersih sehingga ROE. Penelitian Lenka (2017) mengidentifikasi pengaruh DER terhadap ROE dapat positif dan negatif tergantung pada sektornya. Hasil penelitian ini sejalan dengan penelitian yang dilakukan oleh Marinda, et.al. di sektor properti dan real estate (2014); Murniati, et. al. (2019) di sektor manufaktur; Nopitasari, et. al.di sektor properti dan real estate (2014); Utamayasa dan Suputra di sektor properti (2016). Namun bertentangan dengan hasil penelitian Nurcahayani dan Daljono (2014) serta Dewi dan Wirajaya (2013) di sektor manufaktur; Hantono (2015) di sektor manufaktur logam dan sejenisnya yang menunjukkan bahwa DER memiliki pengaruh yang signifikan terhadap ROE dengan arah negatif. Perbedaan hasil dimungkinkan terjadi, karena peningkatan hutang pada tahap awal akan meningkatkan ROE sampai suatu tingkat tertentu maka peningkatan hutang akan menurunkan ROE, karena semakin tinggibeban bunga yang harus dibayarkan.

Kebijakan dividen berpengaruh positif signifikan terhadap kinerja keuangan sebesar $4,73 \%$. Penelitian ini sejalan dengan Arumsari, et. al. (2014); Anandasayanan dan Velmampy (2016); Flint, et. al. (2010); Wiagustini, 2010 dalam Dewi dan Suardana, (2015); Rahman, et. al. (2015); Dewi dan Wirajaya (2013).

Kinerja keuangan (ROE) berpengaruh signifikan terhadap nilai perusahaan. Isyarat atau signal merupakan suatu tindakan yang diambil perusahaan untuk memberi petunjuk bagi investor tentang bagaimana manajemen memandang prospek perusahaan (Brigham dan Houston, 2011). Penelitian ini sejalan dengan Rahman (2015) artinya peningkatan ROE akan meningkatkan harga saham sehingga menambah PBV.

\section{KESIMPULAN}

Kondisi keputusan investasi (PER) berfluktuasi, artinya ketika rasio PER semakin tinggi menunjukkan investasi perusahaan juga tinggi dan merupakan sinyal pertumbuhan pendapatan di masa datang. Kondisi keputusan pendanaan (DER) berfluktuasi cenderung 
menurun, artinya ketika DER kecil maka semakin baik posisi hutang perusahaan. Kondisi kebijakan dividen (DPR) berfluktuasi, artinya semakin besar dividen maka kinerja perusahaan akan dianggap semakinbaik pula. Kondisi kinerja keuangan (ROE) berfluktuasi cenderung menurun, artinya ketika ROE rendah hal tersebut terjadi diakibatkan oleh adanya penurunan laba setelah pajak, sementara total ekuitas perusahaan meningkat atau stagnan. Kondisi nilai perusahaan (PBV) berfluktuasi cenderung menurun. Terdapat pengaruh signifikan keputusan investasi, keputusan pendanaan dan kebijakan dividen terhadap kinerja keuangan sebesar 22,5\%. Keputusan investasi berpengaruh negatif dan signifikan terhadap kinerja keuangan sebesar $10 \%$, sedangkan keputusan pendanaan berpengaruh positif dan signifikan sebesar 7,78\%, dan kebijakan dividen sebesar $4,72 \%$. Besarnya pengaruh kinerja keuangan terhadap nilai perusahaan sebesar $33,7 \%$.

\section{DAFTAR PUSTAKA}

Anandasayanan, S. and Thirunavukkarasu, V., 2016. Dividend policy and corporate profitability econometric analysis of listed manufacturing firms in Sri Lanka. International Journal of Commerce and Management Research, 2(1), pp.53-58.

Ardestani, H.S., Rasid, S.Z.A. and Mehri, R.B.M., 2013. Dividend payout policy, investment opportunity set and corporate financing in the industrial products sector of Malaysia. Journal of applied finance and banking, 3(1), p.123.

Apergis, N., Hassapis, C., Christou, C. and Johnson, S., 2015. International earnings to price ratio convergence: evidence from the European Union. The International Journal of Business and Finance Research, 9(5), pp.37-55.

Ardimas, W. and Wardoyo, W., 2015. Pengaruh Kinerja Keuangan Dan Corporate Social Responsibility Terhadap Nilai Perusahaan Pada Bank Go Public Yang Terdaftar Di BEI. Benefit: Jurnal Manajemen dan Bisnis, 18(1), pp.57-66.

Arumsari, Y.K. and Aisjah, S., 2016. Pengaruh Kepemilikan Manajerial, Kebijakan Utang, Kebijakan Dividen Terhadap Kinerja Keuangan dan Biaya Agensi. Studi pada Perusahaan Manufaktur yang Terdaftar di Bursa Efek Indonesia. Jurnal Wawasan Manajemen, 2(2), pp.171-188.

AS, M.D. and Wijaya, A., 2013. Pengaruh Struktur Modal, Profitabilitas dan Ukuran Perusahaan pada Nilai Perusahaan. E-Jurnal Akuntansi Universitas Udayana, 4(2).

Brigham, E.F. and Houston, J.F., 2019. Fundamentals of Financial Management, 15th Edition. Mason: South-Western Cengage Learning

Daud, W.M.N.W., Norwani, N.M., Mansor, A.A. and Endut, W.A., 2016. Does financing decision influence corporate performance in Malaysia.
International Journal of Economics and Financial Issues, 6(3), pp.1165-1171.

Dewi, L.N. and Suardana, K.A., 2015. Pengaruh keputusan investasi dan good corporate governance pada kinerja keuangan serta implikasinya pada nilai perusahaan. E-Jurnal Akuntansi, pp.786-802.

Flint, A., Tan, A. and Tian, G.G., 2010. Predicting future earnings growth: A test of the dividend payout ratio in the Australian market. The International Journal of Business and Finance Research, 4(2), pp.43-58.

Fengju, X., Yari Fard, R., Ghassab Maher, L. and Akhteghan, N., 2013. The relationship between financial leverage and profitability with an emphasis on income smoothing in Iran's capital market. European Online Journal of Natural and Social Sciences, 2(3 (s)), pp.pp-156.

Gotwald, Radim. 2012. The Use ofthe P/E Ratio to Stock Valuation. GRANT Journal, MAGNANIMITAS Assn. Grant: IGA 31.

Hantono, H., 2015. Pengaruh Current Ratio dan Debt To Equity Ratio Terhadap Profitabilitas pada Perusahaan Manufaktur Sektor Logam dan Sejenisnya yang Terdaftar di Bursa Efek Indonesia Periode 20092013. Jurnal Wira Ekonomi Mikroskil: JWEM, 5(1), pp.21-30.

Hagel, J., Brown, J.S., Samoylova, T., Lui, M., Damani, A. and Grames, C., 2013. Success or Struggle: ROA as a True Measure of Business Performance. Report 3 of the Shift Indeks Series. Deloitte University Press.

Hemastuti, C.P. and Hermanto, S.B., 2014. Pengaruh Profitabilitas, Kebijakan Dividen, Kebijakan Hutang, Keputusan Investasi, dan Kepemilikan Insider Terhadap Nilai Perusahaan. Jurnal Ilmu dan Riset Akuntansi, 3 (4). Hal 1 - 15.

Fahmi, Irham. 2017. Analisis Laporan Keuangan, Alfabeta, Bandung.

Kazmierska-Jozwiak, Bogna; Jakub Marszalek; Pawel Sekula, 2015. Determinants of Debt-Equity Choice - Evidence From Poland. Emerging Markets Journal, Vol. 5 No. 2.

Kibet, B., Joel, T., Thomas, C., Loice, M. and Mary, K., 2010. The Level Of Corporate Dividend Payout To Stockholders: Does Optimal Dividend Policy Exist For Firms Quoted At The Nairobi Stock Exchange?. International Business \& Economics Research Journal (IBER), 9(3).

Lenka, S., 2017. The relationship between company returns and leverage depending on the business sector: empirical evidence from the Czech Republic. Journal of Competitiveness, 9(3), p.98.

Manjunatha K. 2013. Impact of Debt-Equity and Dividend Payout Ratio on the Value of the Firm. Global Journal of Commerce \& Management Perspective. Vol. 2 (2): $18-27$.

Marinda, F., 2014. Pengaruh investment opportunity set (IOS) dan struktur modal terhadap kinerja keuangan 
(Studi pada perusahaan sektor properti dan real estate yang terdaftar di Bursa Efek Indonesia periode 2011-2013). Jurnal Administrasi Bisnis, 14(1).

Murniati, S., Mus, H.A.R., Semmaila, H.B. and Nur, H.A.N., 2019. Effect of Investment Decisions, Financing Decisions and Dividend Policy on Profitability and Value of The Firm. International Journal of Accounting \& Finance in Asia Pasific (IJAFAP), 2(1).

Nopitasari, H., Tiorida, E. and Sarah, I.S., 2017. Pengaruh Financial Leverage Terhadap Kinerja Keuangan (Studi Pada Perusahaan Properti dan Real Estate yang Terdaftar di Bursa Efek Indonesia Periode 2011-2015). Jurnal Riset Bisnis dan Investasi, 3(3), pp.45-56.

Nurcahyani, R. and Daljono, D., 2014. Analisis Pengaruh Struktur Modal terhadap Profitabilitas. Studi Pada Perusahaan Manufaktur yang Terdaftar di Bursa Efek Indonesia Pada Tahun 2010 - 2012. Diponegoro Journal of Accounting. Vol. 3, No. 4.

Rahman, A., Agusti, R. and Rofika, R., 2015. Pengaruh Kebijakan Dividen; Kebijakan Utang; Keputusan Investasi, dan Profitabilitas terhadap Nilai Perusahaan pada Perusahaan Manufaktur yang Terdaftar di BEI. Jom FEKON, Vol. 2 No. 2.

San Ong, T., Yichen, Y.N. and Teh, B.H., 2010. Can high price earnings ratio act as an indicator of the coming bear market in the Malaysia?. International Journal of Business and Social Science, 1(1).

Sari, Oktavina Tiara. 2013. Pengaruh Keputusan Investasi, Keputusan Pendanaan dan Kebijakan Dividen Terhadap Nilai Perusahaan. Management Analysis Journal Vol.2 No.2, 1-7.

Sezgin, Funda H. 2010. An Empirical Investigation of the Relationship among P/E Ratio, Stock Return and Dividend Yields for Istanbul Stock Exchange. International Journal of Economics and Finance Studies. Vol. 2 No. 1.

Sutrisno. 2012. Manajemen Keuangan. Teori, Konsep, dan Aplikasi. Yogyakarta. Ekonisia.

Syahyunan. 2013. Manajemen Keuangan: Perencanaan, Analisis, dan Pengendalian Keuangan. USU press. Medan.

Utamayasa, I.M.A.K. and Suputra, I.D.D., 2016. Pengaruh Sumber Pendanaan dan Keputusan Investasi pada Nilai Perusahaan Sektor Properti pada Bursa Efek Indonesia. E-Jurnal Ekonomi dan Bisnis Universitas Udayana 5.8.

Wu, W. 2013. The Forward P/E Ratio and Earning Growth (Working Paper). University of Massachusets Boston. Retrieved from http://papers.Ssrn.com/so 13/ papers.cfm?abstract_id $=1014177$

$\mathrm{Wu}, \mathrm{W} .2014$. The P/E Ratio and Profitability. Journal of Business \& Economics Research - First Quarter. Vol. 12. No. 1.

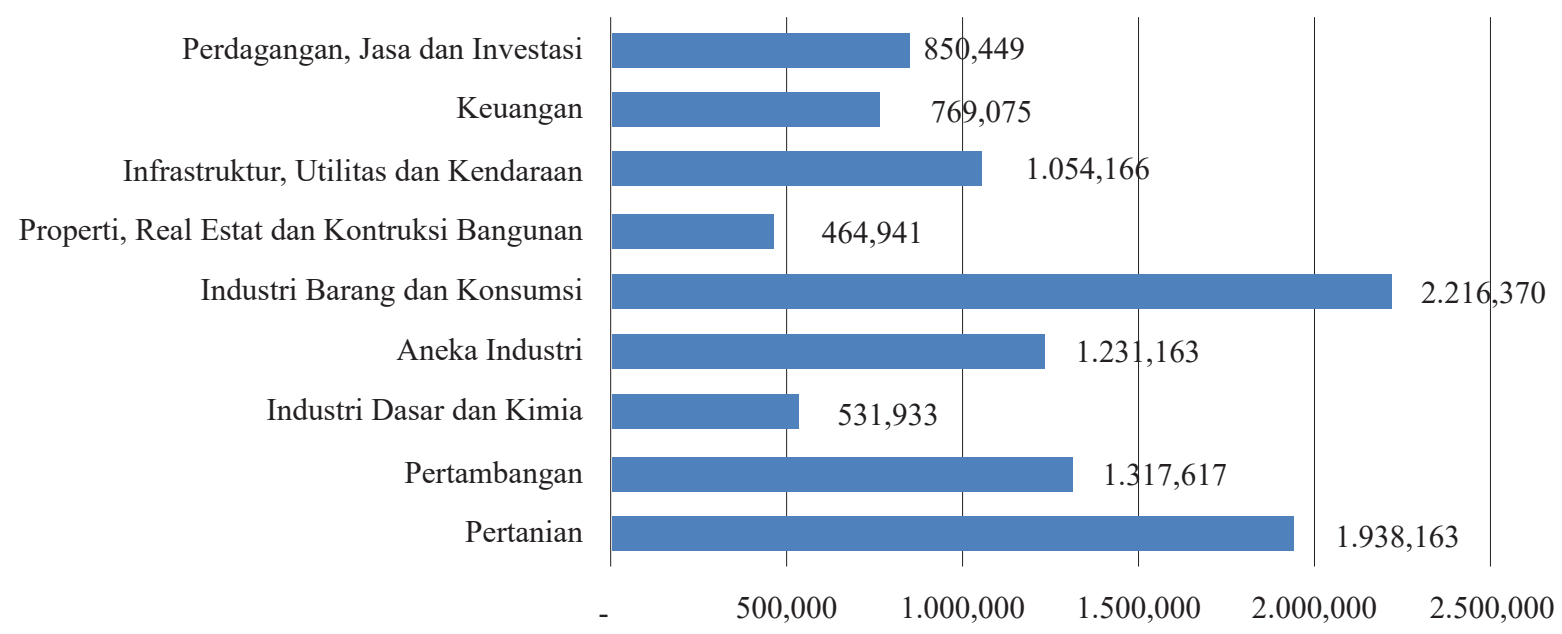

Sumber: www.idx.co.id (data diolahkembali 2019)

Gambar 1. Grafik Rata-Rata Harga Saham Sektoral yang Tercatat di BEI Periode 2012-2017 


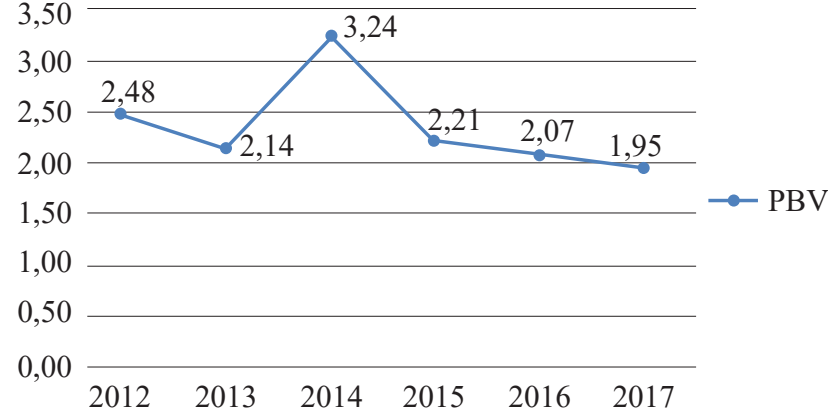

Sumber: www.idx.co.id (data diolah kembali 2019)

Gambar 2. Grafik Rata-Rata Nilai Perusahaan SektorProperti Real Estate dan Konstruksi Bangunan yang Terdaftar di BEI Periode 2012-2017

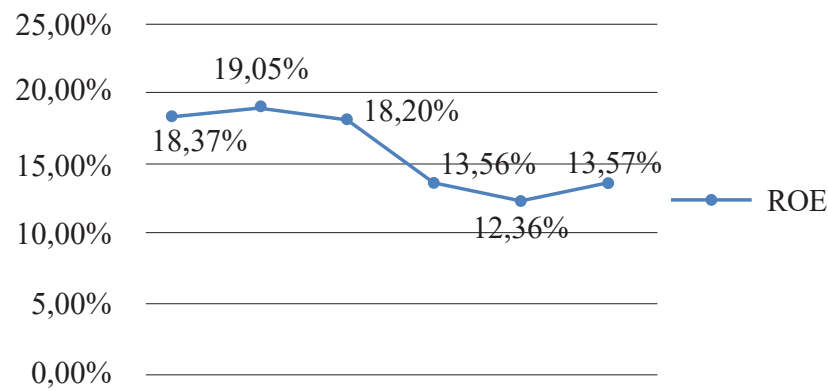

$2012 \quad 20132014 \quad 2015 \quad 2016 \quad 2017$

Sumber: www.idx.co.id (data diolah kembali 2019)

Gambar 3. Grafik Rata-Rata Kinerja Keuangan Sektor Properti Real Estate dan Konstruksi Bangunan yang Terdaftar di BEI Periode 2012-2017

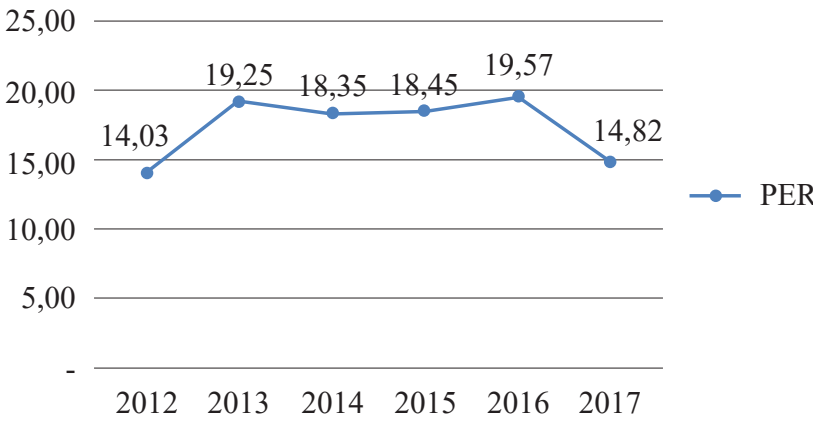

Sumber: www.idx.co.id (data diolah kembali 2019)

Gambar 4. Grafik Rata-Rata Keputusan Investasi Sektor Properti, Real Estate, dan Konstruksi Bangunan yang Terdaftar di BEI Periode 2012-2017

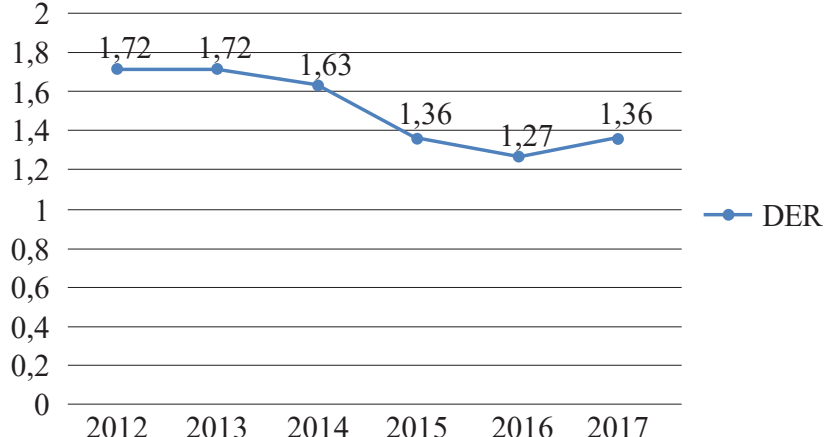

Sumber: www.idx.co.id (data diolah kembali 2019)

Gambar 5. Grafik Rata-Rata Keputusan Pendanaan Sektor Properti, Real Estate, dan Konstruksi Bangunan yang Terdaftar di BEI Periode 2012-2017

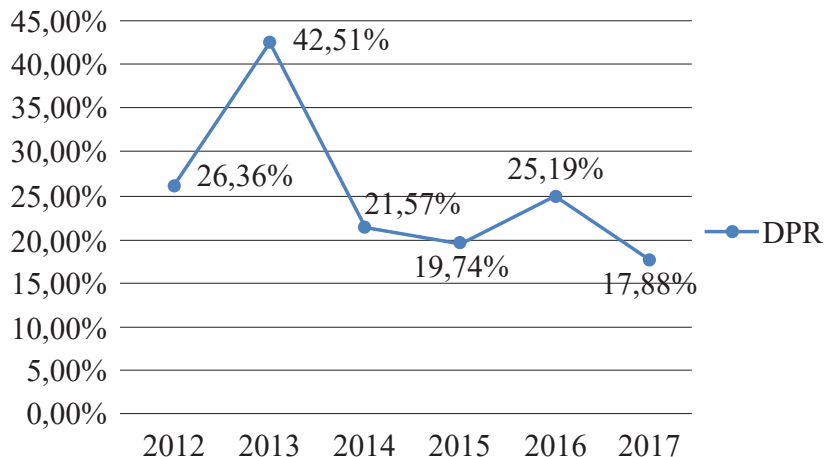

Sumber: www.idx.co.id (data diolah kembali 2019)

Gambar 6. Grafik Rata-rata Kebijakan Dividen Sektor Properti, Real Estate, dan Konstruksi Bangunan yang Terdaftar di BEI Periode 2012-2017

Tabel 1. Price Earning Ratio Perusahaan Sektor Properti, Real Estate, dan Konstruksi Bangunan Periode 2012-2017

\begin{tabular}{|c|c|c|c|c|c|c|c|}
\hline \multirow{2}{*}{ No } & \multirow[t]{2}{*}{ Kode } & \multicolumn{6}{|c|}{ Tahun } \\
\hline & & 2012 & 2013 & 2014 & 2015 & 2016 & 2017 \\
\hline 1. & ASRI & 11,76 & 9,56 & 10,00 & 11,43 & 13,54 & 4,68 \\
\hline 2. & BEST & 12,06 & 5,78 & 17,99 & 13,40 & 7,29 & 4,54 \\
\hline 3. & BSDE & 15,10 & 8,39 & 8,54 & 16,01 & 18,81 & 6,65 \\
\hline 4. & CTRA & 14,29 & 11,72 & 14,37 & 17,38 & 23,84 & 24,69 \\
\hline 5. & DILD & 17,63 & 10,16 & 7,83 & 12,54 & 17,24 & 12,07 \\
\hline 6. & GMTD & 1,04 & 9,16 & 5,09 & 6,41 & 8,12 & 15,14 \\
\hline 7. & GPRA & 7,69 & 6,54 & 14,29 & 9,44 & 17,99 & 13,83 \\
\hline 8. & JRPT & 19,87 & 20,11 & 18,61 & 11,47 & 11,66 & 10,97 \\
\hline 9. & LPKR & 9,26 & 16,87 & 9,12 & 44,02 & 18,58 & 18,09 \\
\hline 10. & MTLA & 20,00 & 11,94 & 12,59 & 7,63 & 9,99 & 6,75 \\
\hline 11. & PWON & 14,06 & 11,48 & 9,86 & 18,93 & 16,29 & 17,61 \\
\hline 12. & SMRA & 17,27 & 10,21 & 15,68 & 27,83 & 61,34 & 37,65 \\
\hline 13. & ADHI & 14,79 & 6,70 & 19,34 & 10,55 & 23,63 & 13,02 \\
\hline 14. & РТPP & 12,97 & 13,33 & 32,50 & 25,33 & 23,09 & 11,28 \\
\hline 15. & TOTL & 16,98 & 8,78 & 23,33 & 10,96 & 11,70 & 9,20 \\
\hline 16. & WIKA & 17,83 & 17,02 & 36,73 & 25,93 & 14,88 & 11,56 \\
\hline 17. & WSKT & 17,31 & 10,60 & 28,32 & 18,52 & 17,29 & 7,78 \\
\hline & Rata-Rat & 14,11 & 11,08 & 16,72 & 16,93 & 18,55 & 13,27 \\
\hline & Tertinggi & 20,00 & 20,11 & 36,73 & 44,02 & 61,34 & 37,65 \\
\hline & Terendah & 1,04 & 5,78 & 5,09 & 6,41 & 7,29 & 4,54 \\
\hline
\end{tabular}

Sumber :www.idx.co.id (data diolah kembali 2019) 
Tabel 2. Debt Equity Ratio Perusahaan Sektor Properti, Real Estate dan Konstruksi Bangunan Periode 2012-2017

\begin{tabular}{|c|c|c|c|c|c|c|c|}
\hline \multirow{2}{*}{ No } & \multirow{2}{*}{$\begin{array}{c}\text { Kode } \\
\text { Perusahaan }\end{array}$} & \multicolumn{6}{|c|}{ Tahun } \\
\hline & & 2012 & 2013 & 2014 & 2015 & 2016 & 2017 \\
\hline 1. & ASRI & 1,31 & 1,71 & 1,66 & 1,83 & 1,81 & 1,42 \\
\hline 2. & BEST & 0,29 & 0,36 & 0,28 & 0,52 & 0,54 & 0,23 \\
\hline 3. & BSDE & 0,75 & 0,68 & 0,52 & 0,63 & 0,58 & 0,57 \\
\hline 4. & CTRA & 0,77 & 1,06 & 1,04 & 1,01 & 1,03 & 1,05 \\
\hline 5. & DILD & 0,54 & 0,84 & 1,01 & 1,16 & 1,34 & 1,08 \\
\hline 6. & GMTD & 2,85 & 2,24 & 1,29 & 1,30 & 0,92 & 0,77 \\
\hline 7. & GPRA & 0,86 & 0,66 & 0,71 & 0,66 & 0,55 & 0,45 \\
\hline 8. & JRPT & 1,25 & 1,30 & 1,08 & 0,83 & 0,73 & 0,58 \\
\hline 9. & LPKR & 1,17 & 1,21 & 1,14 & 1,18 & 1,07 & 0,90 \\
\hline 10. & MTLA & 0,30 & 0,61 & 0,60 & 0,64 & 0,57 & 0,62 \\
\hline 11. & PWON & 1,41 & 1,27 & 1,02 & 0,99 & 0,88 & 0,83 \\
\hline 12. & SMRA & 1,85 & 1,93 & 1,57 & 1,49 & 1,55 & 1,59 \\
\hline 13. & $\mathrm{ADHI}$ & 5,67 & 5,28 & 4,97 & 2,25 & 2,69 & 3,83 \\
\hline 14. & РТРP & 4,16 & 5,26 & 5,11 & 2,72 & 1,90 & 1,93 \\
\hline 15. & TOTL & 1,92 & 1,72 & 2,11 & 2,29 & 2,13 & 0,69 \\
\hline 16. & WIKA & 2,89 & 2,90 & 2,20 & 2,60 & 1,49 & 2,12 \\
\hline \multirow[t]{4}{*}{17.} & WSKT & 3,17 & 2,69 & 3,40 & 2,12 & 2,66 & 3,30 \\
\hline & Rata-Rata & 1.83 & 1.87 & 1.75 & 1.42 & 1.32 & 1.29 \\
\hline & Tertinggi & 5.67 & 5.28 & 5.11 & 2.72 & 2.69 & 3.83 \\
\hline & Terendah & 0.29 & 0.36 & 0.28 & 0.52 & 0.54 & 0.23 \\
\hline
\end{tabular}

Sumber :www.idx.co.id (data diolah kembali 2019)

Tabel 3. Dividend Payout Ratio Perusahaan Sektor Properti, Real Estate, dan Konstruksi Bangunan Periode 2012-2017

\begin{tabular}{|c|c|c|c|c|c|c|c|}
\hline \multirow{2}{*}{ No } & \multirow{2}{*}{$\begin{array}{c}\text { Kode } \\
\text { Perusa- } \\
\text { haan }\end{array}$} & \multicolumn{6}{|c|}{ Tahun } \\
\hline & & 2012 & 2013 & 2014 & 2015 & 2016 & 2017 \\
\hline 1. & ASRI & 28,6 & & $12,50 \%$ & $5,00 \%$ & $5,77 \%$ & $1,97 \%$ \\
\hline 2. & BEST & 17 & $2,93 \%$ & $5,62 \%$ & $5,61 \%$ & $9,85 \%$ & $19,96 \%$ \\
\hline 3. & BSDE & 20,4 & $9,75 \%$ & $6,90 \%$ & $4,09 \%$ & $4,72 \%$ & $1,85 \%$ \\
\hline 4. & CTRA & $21,43 \%$ & $26,69 \%$ & $6,76 \%$ & $6,71 \%$ & $6,26 \%$ & $17,31 \%$ \\
\hline 5. & DILD & 26,32 & 25,8 & $23,97 \%$ & $12,37 \%$ & & $8 \%$ \\
\hline 6. & GMTD & & 5,5 & $5,42 \%$ & $3,84 \%$ & $2,92 \%$ & $2,38 \%$ \\
\hline 7. & GPRA & 15,3 & 8,6 & 1 & 29 , & & $\%$ \\
\hline 8. & JRPT & 33,9 & 32 & 33 & 33 & & $\%$ \\
\hline 9. & LPKR & & & 0 & 0 & & $\%$ \\
\hline 10. & MTLA & 19, & & 9,9 & & & \\
\hline 11. & PWON & 21 , & & 8,3 & 15 & & $7 \%$ \\
\hline 12. & SMRA & 39 & & 20 & 6 , & & \\
\hline 13. & ADHI & 19,7 & & 1 & 20 , & & $4 \%$ \\
\hline 14. & РТРP & 29,9 & 29 , & 19,9 & 17 & & $16,86 \%$ \\
\hline 15. & TOTL & 55,3 & & 62 & 71 , & & $2 \%$ \\
\hline 16. & WIKA & 26,8 & 30,0 & $16,40 \%$ & 17,8 & & $17,74 \%$ \\
\hline 17. & WSKT & & & $19,88 \%$ & $20,01 \%$ & & $18,48 \%$ \\
\hline & Rata-R & & & 17 , & & & $1 \%$ \\
\hline & Tertinggi & & & & & & $73,72 \%$ \\
\hline & Terendah & & & $5,42 \%$ & $4,09 \%$ & 3, & $1,97^{\circ}$ \\
\hline
\end{tabular}

Tabel 4. Return on Equity Perusahaan Sektor Properti, Real Estate, dan Konstruksi Bangunan Periode 2012-2017

\begin{tabular}{lllllll}
\hline & Kode & \multicolumn{6}{c}{ Tahun } \\
\cline { 2 - 7 } No $\begin{array}{c}\text { Perusa- } \\
\text { haan }\end{array}$ & 2012 & 2013 & 2014 & 2015 & 2016 & 2017 \\
\hline
\end{tabular}

1. ASRI 25,70\% $16,68 \% 18,47 \% \quad 10,36 \% \quad 7,10 \% 16,16 \%$

2. BEST $26,57 \% 30,07 \% 13,73 \% \quad 6,97 \% \quad 9,92 \% 12,56 \%$

3. BSDE $5,80 \% 21,66 \% 21,63 \% \quad 10,64 \% \quad 8,33 \% \quad 17,70 \%$

4. CTRA $10,02 \% \quad 14,47 \% \quad 15,71 \% \quad 13,34 \% \quad 8,19 \% \quad 6,59 \%$

5. DILD $\quad 5,07 \% \quad 8,05 \% \quad 9,67 \% \quad 8,78 \% \quad 5,88 \% \quad 4,30 \%$

6. GMTD 27,52\% 22,77\% 18,01\% 21,38\% 13,61\% 9,69\%

7. GPRA $\quad 8,01 \% 13,30 \% 10,29 \% \quad 7,70 \% \quad 4,65 \% \quad 3,61 \%$

8. JRPT $19,26 \% 20,36 \% 22,68 \% 21,00 \% 20,75 \% 18,69 \%$

9. LPKR $11,53 \% 11,23 \% \quad 17,77 \% \quad 5,41 \% \quad 5,56 \% \quad 2,87 \%$

10. MTLA $13,12 \% 13,65 \% 15,18 \% 10,84 \% 12,65 \% 18,37 \%$

11. PWON $24,45 \% 27,70 \% 31,38 \% \quad 14,81 \% 16,16 \% \quad 15,83 \%$

12. SMRA $\quad 20,76 \% 23,53 \% 23,15 \% \quad 14,13 \% \quad 7,41 \% \quad 6,37 \%$

13. ADHI $\quad 18,06 \% 26,38 \% \quad 18,65 \% \quad 9,01 \% \quad 5,79 \% \quad 8,81 \%$

14. PTPP $\quad 18,70 \% 21,20 \% 22,26 \% \quad 16,42 \% \quad 10,66 \% 12,10 \%$

15. TOTL $\quad 25,75 \% 26,03 \% 20,49 \% 22,08 \% 23,48 \% \quad 7,13 \%$

16. WIKA $\quad 18,46 \% 19,35 \% \quad 15,08 \% \quad 12,93 \% \quad 9,18 \% \quad 9,27 \%$

17. WSKT $\quad 12,66 \% 15,44 \% 17,59 \% \quad 10,80 \% 10,81 \% \quad 18,46 \%$

Rata-Rata 17,14\% 19,52\% 18,34\% 12,74\% 10,60\% $11,09 \%$

Tertinggi 27,52\% 30,07\% 31,38\% 22,08\% 23,48\% 18,46\%

$\begin{array}{lllllll}\text { Terendah } & 5,07 \% & 8,05 \% & 9,67 \% & 5,41 \% & 4,65 \% & 3,61 \%\end{array}$

Sumber :www.idx.co.id (data diolah kembali 2019)

Tabel 5. Price Book Value Perusahaan Sektor Properti, Real Estate, dan Konstruksi Bangunan Periode 2012-2017

\begin{tabular}{|c|c|c|c|c|c|c|c|}
\hline \multirow{2}{*}{ No } & \multirow{2}{*}{$\begin{array}{c}\text { Kode } \\
\text { Perusahaan }\end{array}$} & \multicolumn{6}{|c|}{ Tahun } \\
\hline & & 2012 & 2013 & 2014 & 2015 & 2016 & 2017 \\
\hline 1. & ASRI & 2,82 & 1,59 & 1,73 & 1,02 & 1,05 & 0,84 \\
\hline 2. & BEST & 3,6 & 1,73 & 2,47 & 0,93 & 0,72 & 0,66 \\
\hline 3. & BSDE & 1,84 & 1,68 & 1,79 & 1,57 & 1,39 & 1,23 \\
\hline 4. & CTRA & 1,43 & 1,16 & 1,66 & 1,72 & 1,44 & 1,47 \\
\hline 5. & DILD & 0,88 & 0,80 & 1,51 & 1,06 & 1,02 & 0,61 \\
\hline 6. & GMTD & 0,29 & 2,09 & 0,93 & 1,37 & 1,1 & 1,49 \\
\hline 7. & GPRA & 0,61 & 0,81 & 1,44 & 0,90 & 0,78 & 0,43 \\
\hline 8. & JRPT & 3,84 & 4,10 & 4,46 & 2,48 & 2,45 & 2,23 \\
\hline 9. & LPKR & 2,01 & 1,48 & 1,33 & 1,26 & 0,75 & 0,48 \\
\hline 10. & MTLA & 2,63 & 1,63 & 1,65 & 0,74 & 1,08 & 1,16 \\
\hline 11. & PWON & 3,46 & 3,18 & 2,99 & 2,53 & 2,47 & 2,68 \\
\hline 12. & SMRA & 3,59 & 2,41 & 3,66 & 3,16 & 2,34 & 1,65 \\
\hline 13. & ADHI & 2,68 & 1,76 & 3,58 & 1,48 & 1,36 & 1,21 \\
\hline 14. & РТРP & 2,43 & 2,83 & 7,24 & 3,67 & 2,19 & 1,31 \\
\hline 15. & TOTL & 4,35 & 2,08 & 4,79 & 2,42 & 2,77 & 2,32 \\
\hline 16. & WIKA & 3,21 & 3,00 & 4,54 & 2,99 & 1,69 & 1,06 \\
\hline & WSKT & 2,16 & 1,64 & 5,02 & 2,34 & 2,06 & 1,37 \\
\hline & Rata-Rata & 2.46 & 2.00 & 2.99 & 1.86 & 1.57 & 1.31 \\
\hline & Tertinggi & 4.35 & 4.1 & 7.24 & 3.67 & 2.77 & 2.32 \\
\hline & Terendah & 0.29 & 0.8 & 0.93 & 0.74 & 0.72 & 0.43 \\
\hline
\end{tabular}


Tabel 6. Coefficients Persamaan I

\begin{tabular}{|c|c|c|c|c|c|c|c|c|c|}
\hline \multicolumn{10}{|c|}{ Coefficients $^{\mathrm{a}}$} \\
\hline \multirow{2}{*}{\multicolumn{2}{|c|}{ Model }} & \multicolumn{2}{|c|}{$\begin{array}{l}\text { Unstandardized } \\
\text { Coefficients }\end{array}$} & \multirow{2}{*}{$\begin{array}{c}\text { Standardized } \\
\text { Coefficients } \\
\text { Beta }\end{array}$} & \multirow[b]{2}{*}{$\mathrm{t}$} & \multirow[b]{2}{*}{ Sig. } & \multicolumn{3}{|c|}{ Correlations } \\
\hline & & B & $\begin{array}{l}\text { Std. } \\
\text { Error }\end{array}$ & & & & $\begin{array}{l}\text { Zero- } \\
\text { order }\end{array}$ & Partial & Part \\
\hline 1 & (Constant) & 4.037 & .416 & & 9.712 & .000 & & & \\
\hline & Keputusan Investasi & -.428 & .104 & -.382 & -4.105 & .000 & -.261 & -.383 & -.365 \\
\hline & Keputusan Pendanaan & .637 & .203 & .297 & 3.143 & .002 & .262 & .303 & .280 \\
\hline & KebijakanDividen & .128 & .055 & .218 & 2.330 & .022 & .217 & .229 & .207 \\
\hline
\end{tabular}

a. Dependent Variable: Kinerja Keuangan

Sumber: Hasil pengolahan output SPSS (data diolah 2019)

Tabel 7. Coefficients Persamaan II

\begin{tabular}{|c|c|c|c|c|c|c|c|c|}
\hline \multicolumn{9}{|c|}{ Coefficients $^{\mathrm{a}}$} \\
\hline \multirow[b]{2}{*}{ Model } & \multicolumn{2}{|c|}{$\begin{array}{c}\text { Unstandardized } \\
\text { Coefficients }\end{array}$} & $\begin{array}{l}\text { Standardized } \\
\text { Coefficients }\end{array}$ & \multirow[b]{2}{*}{$\mathrm{t}$} & \multirow[b]{2}{*}{ Sig. } & \multicolumn{3}{|c|}{ Correlations } \\
\hline & B & $\begin{array}{l}\text { Std. } \\
\text { Error }\end{array}$ & Beta & & & $\begin{array}{l}\text { Zero- } \\
\text { order }\end{array}$ & Partial & Part \\
\hline $\begin{array}{ll}1 & \text { (Constant) }\end{array}$ & .416 & .138 & & 3.015 & .003 & & & \\
\hline KinerjaKeuangan & .254 & .036 & .580 & 7.122 & .000 & .580 & .580 & .580 \\
\hline
\end{tabular}

a. Dependent Variable: Nilai Perusahaan

Sumber: Hasil pengolahan output SPSS (data diolah 2019)

Tabel 8. Hasil Koefisien Determinasi Simultan Persamaan I

\begin{tabular}{ccrrr}
\multicolumn{5}{c}{ Model Summary } \\
\hline Model & $\mathrm{R}$ & $\mathrm{R}$ & $\begin{array}{c}\text { Adjusted R } \\
\text { Square }\end{array}$ & $\begin{array}{c}\text { Std. Error of the } \\
\text { Estimate }\end{array}$ \\
\hline 1 & $.474^{\mathrm{a}}$ & .225 & .201 & .80934
\end{tabular}

a. Predictors: (Constant), Kebijakan Dividen, Keputusan Investasi, Keputusan Pendanaan

Sumber: Hasil pengolahan output SPSS (data diolah 2019)
Tabel 9. Hasil Koefisien Determinasi Simultan Persamaan II

\begin{tabular}{crrrr}
\multicolumn{5}{c}{ Model Summary } \\
\hline Model & $\mathrm{R}$ & $\begin{array}{c}\mathrm{R} \\
\text { Square }\end{array}$ & $\begin{array}{c}\text { Adjusted R } \\
\text { Square }\end{array}$ & $\begin{array}{l}\text { Std. Error of } \\
\text { the Estimate }\end{array}$ \\
\hline 1 & $.580^{\mathrm{a}}$ & .337 & .330 & .32514
\end{tabular}

a. Predictors: (Constant), Kinerja Keuangan

Sumber: Hasil pengolahan output SPSS (data diolah 2019) 